\title{
RESEARCH NOTE \\ Stability analysis of forage production in Bromus catharticus (prairie grass) using three methodologies
}

\author{
Liliana Abbott, Susana Filippini, Hugo Delfino, and Susana Pistorale \\ Departamento de Ciencias Básicas, Universidad Nacional de Luján, CC 221, (6700) Luján, Buenos Aires, \\ Argentina.
}

\begin{abstract}
L. Abbott, S. Filippini, H. Delfino and S. Pistorale. 2012. Stability analysis of forage production in Bromus catharticus (prairie grass) using three methodologies. Cien. Inv. Agr. 39(2): 331-338. Thirteen genotypes of Bromus catharticus (prairie grass) were evaluated for forage production over three years using completely randomized trials with six replicates. The genotype $\mathrm{x}$ environment interaction was statistically significant and indicates that the behavior of genotypes differs over time. Once this interaction was detected, we used three methodologies to assess the stability of genotypes: Wricke's ecovalence, the Lin and Binns index, and the Eberhart and Russell model. The methods of Lin and Binns and Eberhart and Russell indicate that genotypes 11, 9, 3 and 4 are stable. They also rule out possible selection of genotypes 2, 10,1 and 12 for lack of stability or poor adaptation. The correlation among these indices was statistically significant $(\mathrm{r}=0.61)$. When using Wricke's ecovalence, there is agreement among the indices for the selection of genotypes 9 and 4, which show good stability. There is no agreement with the other two methods for ruling out unstable genotypes. Considering the three methodologies used, the Lin and Binns index is easiest to apply and interpret because higher productivity always correlates with greater stability, and there are no restrictions on the use of regression. However, it is necessary to accumulate more data prior to the widespread use of these methods.
\end{abstract}

Key words: Bromus, forage production, genotype-environment interaction, phenotypic stability, prairie grass

\section{Introduction}

Prairie grass (Bromus catharticus Vahl., syn. B. willdenowii Kunth, B. unioloides Kunth, also called rescue-prairie grass or grass) is an autogamous forage that is planted in large areas over a wide range of environments. Climate and

Received June 7, 2011. Accepted December 20, 2011 Corresponding author: genetica@unlu.edu.ar soil factors often lead to differential responses in materials of different origin. For this reason, studies of genotype $(\mathrm{G})$ by environment(E) interaction $(\mathrm{G} \times \mathrm{E})$ and phenotypic stability are of particular interest for the genetic enhancement of this species.

Grass tillering ability has a direct impact on pasture establishment and longevity. From a production standpoint, tiller number and weight are the main components that determine forage 
production in pasture (Jewis, 1972; Zarrough, 1983; Jatimliansky et al., 1997).

Concerning genetic improvement, the number of tillers per plant was found to be highly correlated $(\mathrm{P} \leq 0.001)$ with forage fitness, total seed weight and the dry weight of accumulated forage (Guillén, 2002).

The potential tillering rate is determined by the number of tillers, specifically tillers appearing when all tiller buds have developed at the leaf base. Therefore, the number of tillers is used as a selection criterion for forage production (Simon and Lemaire, 1987).

The $\mathrm{G} \times \mathrm{E}$ interaction is described as the inconsistent behavior between genotypes from one environment to another; when it occurs to a great extent, it reduces the genetic progress of selection (Yang and Baker, 1991; Magari and Kang, 1993). Campbell and Jones (2005) define $\mathrm{G} \times \mathrm{E}$ interaction as the differential response of genotypes for a given trait in different environments. In general, characteristics of agronomic interest present continuous distribution, possess polygenic inheritance and are strongly influenced by environmental changes (Chaves, 2001).

The definition of environment has been discussed extensively by many researchers. Allard (1960) defines the environment as the sum of all external conditions affecting the growth and development of an organism. For Lin and Binns (1988), the effect of the environment on a genotype depends on soil and atmospheric conditions.

Despite being of great importance for breeding, studies of $\mathrm{G} \times \mathrm{E}$ interaction do not provide information about the behavior of each genotype against environmental variations. Adaptability and stability analyses are performed for that purpose, allowing the identification of cultivars with expected behaviors and responses to environmental variations (Cruz et al., 2004).
Heinrich et al. (1983) define the stability of one character as the ability of a genotype to avoid substantial fluctuations over a range of environmental conditions. Laing (1978) defines stability as the relative response of a genotype to environmental changes in a specific location, and distinguishes between spatial stability, variation between replicates in the same locality and temporal stability that varies from year to year.

From a physiological point of view, the morphological and phenological mechanisms that influence performance stability are genetic heterogeneity, compensation in yield components, stress tolerance, and the capability of rapid recovery from stress (Heinrich et al., 1983).

The performance of genotypes in different locations is evaluated for adaptability. Eberhart and Russell (1966) published several results and concluded that a stable variety is one that does not interact with the environment but is more responsive to environmental changes. Adaptability is a property or ability of a genotype, or population of genotypes, that allows an alteration of the rules of adaptation in response to different pressures of selection (Simmonds, 1979).

Pandey and Vargas (1985) indicate that with self-pollinated species, where populations are of homozygous genotypes, each plant can adapt to a group of environmental conditions and have individual buffers.

The aim of this study was to analyze the performance of 13 genotypes of prairie grass grown in different environmental conditions over a period of three years. We measured the $\mathrm{G} \times \mathrm{E}$ interaction and studied the stability of the genotypes for forage production, indicated by the number of tillers per plant, using three methodologies: Wricke's ecovalence, the Lin and Binns index, and the Eberhart and Russell model. 


\section{Material and methods}

\section{Materials}

In 1990, studies of the reproductive behavior of prairie grass began with natural populations located in three locations in the province of Buenos Aires, Argentina: Luján ( $34^{\circ} 34^{\prime}$ S, 59 $60^{\circ}$ W), Gowland ( $\left.34^{\circ} 41^{\prime} \mathrm{S}, 59^{\circ} 23^{\prime} \mathrm{W}\right)$ and Alberti $\left(35^{\circ}\right.$ $\left.10^{\prime} \mathrm{S}, 60^{\circ} 16^{\prime} \mathrm{W}\right)$.

In each of these populations, plants were selected in situ that showed the best performance in the following areas: number of tillers per plant, number of panicles per plant, survivability and quality seed weight and germination. The progeny of these plants were subjected to progeny testing between 1994 and 1998 to estimate genetic parameters (Wolff et al., 2006). Thirteen genotypes were selected and evaluated.

\section{Design, statistical and genetic analysis}

The plants were first grown in pots and then placed in the experimental field of the Universidad Nacional de Luján (Buenos Aires, Argentina). We conducted a randomized trial with 13 treatments (genotypes) and six replicates, where the experimental unit was a single plant. Agricultural practices, sowing date, transplanting, and irrigation were the same over three years. What changed over time were climatic conditions; in this work, the environment was considered to be the yearly climatic condition.

Characters were analyzed using the 2008 version of the InfoStat program (Estadística y Biometría, Facultad de Ciencias Agropecuarias, Universidad Nacional de Córdoba, Argentina). The variability among genotypes over three years was evaluated with a multivariate analysis of variance.

To measure G x E interaction, data obtained over three years were analyzed according to the following statistical model:
$Y_{i j}=\mu+\alpha_{i}+\beta_{j}+(\alpha \beta)_{i j}+\varepsilon_{i j}$, where $Y_{i j}=$ mean of variety $i$ in environment $\mathrm{j}, \mu=$ overall mean, $\alpha \mathrm{i}$ $=$ effect genotype $i, i=1-13, \beta_{\mathrm{j}}=$ effect of year $j$ (environment), $j=1-3,(\alpha \beta)_{i j}=$ interaction effect of genotype $i$ in year $j$, and $\varepsilon_{i j}=$ random effect or experimental error.

Once G x E interaction was detected, stability was analyzed using three methods:

\section{Ecovalence method}

This is the simplest method, based on the dynamic concept of stability. It was proposed by Wricke (1962), who defines the term ecovalence as the contribution of each genotype in all environments, to the sum of squares of the $\mathrm{G} x \mathrm{E}$ interaction. If ecovalence is small, agronomic stability is high.

Wricke's ecovalence $\left(W_{i}\right)$ was calculated using the following formula:

$W_{i}=S_{j}\left(Y_{i j}-Y_{i .}-Y_{\cdot j}+Y_{. .}\right)^{2}$, where $W_{i}=$ ecovalence value of genotype $i, S_{j}=$ sum of $j$ values in each genotype environment, $Y_{i j}=$ mean of genotype $i$ in environment $j, Y_{i}=$ mean of genotype $i$ in all environments, $Y_{\cdot j}=$ environment average $j$, and $Y .=$ overall average of all environments.

\section{The Lin and Binns index}

The Lin and Binns index (1988) is a single measure of stability and performance superiority of a genotype, defined as the mean square of the distance between the response of a given genotype and the genotype of maximum response in an environment. With this index, the maximum response in an environment becomes the control to consider. The genotype with the lowest ecovalence value is the closest to optimal across environments.

The Lin and Binns index $\left(P_{i}\right)$ was calculated using the following equation: 
$P_{i}=\sum_{j=1}^{a} \frac{\left(\bar{Y}_{i j}-M_{j}\right)^{2}}{2 a}$, where $P_{i}=$ rate stability and superiority of genotype $i, Y_{i j}=$ average yield of genotype $i$ in environment $j, M_{j}=$ maximum yield in environment $j$, and $\mathrm{a}=$ number of environments tested.

\section{The Eberhart and Russell Method}

Eberhart and Russell (1966) proposed a linear regression model to study the phenotypic adaptability of cultivars, which is widely used in such studies throughout the literature. In addition to the general average and linear regression coefficient of each genotype, the variance in the deviations of the regression for each genotype is also considered as a stability parameter in this model. This type of analysis was classified by Becker (1981) as stability in the agronomic sense. The effect of the environment can be dissected into two components, one linear and one nonlinear. The regression coefficient is associated with the linear component, indicating the adaptation of the genotype or its responsiveness among different environments. Deviations from the regression are associated with the nonlinear component and indicate genotypic stability. According to this model, a genotype is stable when it has a higher average than the overall average, a regression coefficient equal to one and deviations from regression that are as small as possible.

Eberhart and Russell established the following model to estimate stability:

$Y_{i j}=\mu_{i}+\beta_{i j}+\delta_{i j}+\varepsilon_{i j}$, where $Y_{i j}=$ average of genotype $i$ in environment $j, \mu_{i}=$ mean of genotype $i$ in all environments, $\beta_{i}=$ regression coefficient measuring the response of genotype $i$ in different environments, $I_{j}=$ environmental index, $\delta_{i j}=$ deviation of the regression of genotype $i$ in environment $j$, and $\varepsilon_{i j}=$ deviation from the regression of the variety and the environment. The index in each environment is calculated by the deviation of the average of all genotypes in this environment in relation to the general average, $I_{j}=Y_{\cdot j}-Y_{. .}$. The regression coefficient of genotype $\mathrm{i}$ is estimated as follows: $\beta_{i}=\frac{\sum Y_{i j} I_{j}}{\sum I_{j}^{2}}$. The second stability parameter is estimated using the following formula: body regression of genotype $\mathrm{i}$ is estimated as: $S_{d i}^{2}=\frac{\sum \delta_{2}^{2}}{n-2}-\frac{s_{e}^{2}}{r}$, where $\delta_{i j}=$ the deviation of genotype $\mathrm{i}$ in environment $\mathrm{j}$ regression and is given as: $\delta_{i j}=Y_{i j}-\hat{\mathrm{Y}}_{i j}$, where $\hat{\mathrm{Y}}_{i j}$ is the expected value of genotype $\mathrm{i}$ in environment $\mathrm{j}$ and where $\frac{s_{e}^{2}}{r}$ is the residual error from combined analysis of variance (which includes all environments).

The following assumptions were made for the parameters of the Eberhart and Russell method: Regression coefficient: H0) $\beta_{i}=1$ tcalculated = $\frac{b_{i}-1}{\sqrt{\operatorname{Var}\left(b_{i}\right)}}$, where $\operatorname{Var}\left(b_{i}\right)=\frac{s_{d i}^{2}}{\sum_{j} I^{2}}$

Deviations from the regression of each genotvpe: H0) $S_{d i}^{2}=0 ; \quad$ Fcalculated $=\frac{\left(\sum j \delta_{i j}^{2} / a-2\right)}{\text { Combined error }}$

\section{Results and discussion}

\section{Variability analysis}

The variability of 13 genotypes over three years was assessed by multivariate tests using Pillai, Wilks, Lawley-Hotelling and Roy statistics. Variability between genotypes were statistically significant $(\mathrm{P} \leq 0.0001)$ for the number of tillers per plant (Peña, 2002; Johnson and Wichern, 2007; Celis de la Rosa, 2008).

\section{Genotype-environment interaction}

Genotype by environment interaction is defined as the differential response of a group of genotypes against different environments. This analysis is used for various stages of evaluation and selection of materials. In this study, individual years were considered to be environments. The differences in environments were caused by climatic variations such as temperature, rainfall and solar radiation in each phenological stage. Figure 1 shows the minimum and maximum average temperatures, 
rainfall and solar radiation. Photosynthetic active radiation (MEGA Jules $\mathrm{m}^{-2}$ ), mean monthly temperature $\left({ }^{\circ} \mathrm{C}\right)$ and monthly total precipitation $(\mathrm{mm})$ were recorded.

Forage production per plant exhibited a statistically significant $\mathrm{G} x \mathrm{E}$ interaction, which means the evaluated genotypes behaved differently from each other over time.

\section{Stability analysis}

Once the presence of $\mathrm{G} x \mathrm{E}$ was observed, stability was estimated using three methods. The Wricke $\left(Y_{i}\right)$ stability parameter was obtained by splitting the mean square of $\mathrm{G} x \mathrm{E}$ into as many components as genotypes were evaluated. Of these, genotypes $12,9,5,4$ and 8 had lower ecovalence values and are considered the most stable. Genotypes 12 and 5 have a lower mean than the grand mean. For this reason, these genotypes will not be considered for the breeding program.

The Lin and Binns index $\left(\mathrm{P}_{i}\right)$ constitutes a single measure of stability and performance superiority of a genotype. With this index, the most stable genotypes were $9,11,3,13$, and 4 . These genotypes had higher performances, which exceeded the overall mean. In Table 1, the ecovalence values, the Lin and Binns index and the ranking for each genotype are shown.

Table 1. Wricke's ecovalency value $W_{i}$, Lin and Binns index $P_{i}$ and ranking of genotypes for forage production per Bromus catharticus plant over three years.

\begin{tabular}{lcccc}
\hline Genotype & $W_{i}(\%)$ & Ranking & $P_{i}$ & Ranking \\
\hline 1 & 7.99 & 10 & 42.60 & 11 \\
2 & 6.89 & 8 & 76.40 & 13 \\
3 & 18.07 & 12 & 5.13 & 3 \\
4 & 1.88 & 4 & 13.65 & 5 \\
5 & 1.19 & 3 & 27.14 & 8 \\
6 & 5.36 & 6 & 22.24 & 7 \\
7 & 5.50 & 7 & 37.38 & 9 \\
8 & 4.60 & 5 & 17.61 & 6 \\
9 & 0.15 & 2 & 1.85 & 1 \\
10 & 9.59 & 11 & 41.69 & 12 \\
11 & 7.27 & 9 & 3.85 & 2 \\
12 & 0.02 & 1 & 39.47 & 10 \\
13 & 31.49 & 13 & 12.95 & 4 \\
\hline & & & & \\
\hline
\end{tabular}

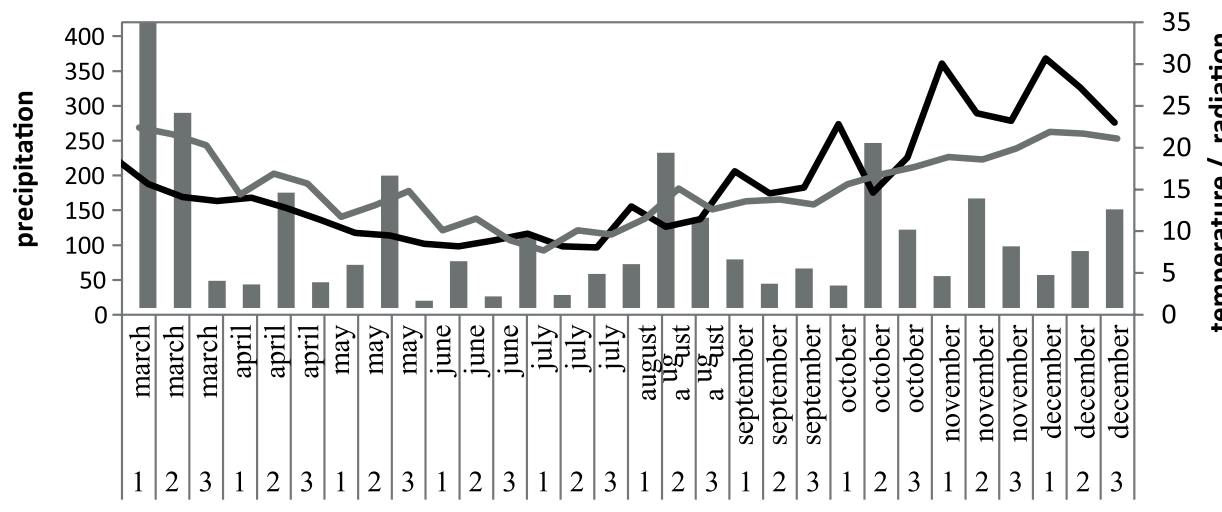

\section{month / year \\ Precipitation Radiation Temperature}

Figure 1. Climatic characterization in the experimental field at the Universidad Nacional de Luján (Buenos Aires, Argentina) during the study period: photosynthetic active radiation (MEGA Jules $\mathrm{m}^{-2}$ ), mean monthly temperature $\left({ }^{\circ} \mathrm{C}\right)$ and monthly total precipitation $(\mathrm{mm})$. 
Table 2 shows the average forage production, adaptability $\left(\beta_{i}\right)$ and stability $\left(S_{d i}^{2}\right)$ parameters of the Eberhart and Russell method for the 13 genotypes. There was sufficient evidence during hypothesis testing to reject $\mathrm{H}_{0}: \beta_{i}=1$ for all genotypes, which indicates that adaptability, whether general or poor, depends on the average being above or below the overall mean, respectively. There was not sufficient evidence to reject $\mathrm{H}_{0}: S_{d i}^{2}=0$ for genotypes $1,3,4$, $5,8,9,10$, and 11 , indicating that they are stable. Using this methodology we could select genotypes $11,9,3,4$ and 8, which have general adaptability, are stable, and their mean exceeds the overall mean. The determination coefficient values are presented in the last column of Table 2. The magnitude of the value of this ratio indicates that the proportion of variance in forage production can be attributed to the variation of the environmental index. These values show that between $24 \%$ and $75 \%$ of the variation in the productivity of genotypes is due to the linear response against environmental changes.

The Lin and Binns and Eberhart and Russell methodologies both indicate that genotypes 11, 9,3 and 4 are stable. They also rule out selection of genotypes 2, 10, 1 and 12 due to their lack of stability or poor adaptation. The correlation among these indices was statistically significant $(\mathrm{r}=0.61)$. When using Wricke's ecovalence, there is only agreement among the indices for the selection of genotypes that show good stability (9 and 4). There is no agreement with the other two methods to rule out unstable genotypes.

All procedures used in this study are included in the parametric approach. Reaching the same conclusion with the thirteen genotypes is difficult. The exceptions are genotypes 9 and 4, which were classified as stable by all three methods. Lin et al. (1986) mentioned that the basic reason for this difficulty is because the response of genotypes to the environment is multivariate, even though the parametric approach attempts to transform it into a univariate problem.

The methodology most used in these studies is the one proposed by Eberhart and Russell. However, Cruz and Salazar (1992) noted that this procedure is controversial because the use of an average response variable per environment as an independent variable is an alleged violation of the assumptions of the models. The approximations based on the linear regression technique are in question because the environmental index, which is usually used as

Table 2. Average forage production, adaptability $\left(\beta_{i}\right)$ and stability $\left(S_{d i}^{2}\right)$ parameters of the Eberhart and Russell method for 13 genotypes of Bromus catharticus over three years.

\begin{tabular}{|c|c|c|c|c|c|c|}
\hline Genotype & Average & $\mu=16.52$ & $\beta_{i}$ & $S_{d i}^{2}$ & Interpretation to all environments & $R^{2}$ \\
\hline 1 & 13.44 & $<$ & 0.68 & 3.65 & Poor adaptation. Stable & 0.43 \\
\hline 2 & 16.39 & $<$ & 1.12 & 13.26 & Poor adaptation. Unstable & 0.50 \\
\hline 3 & 19.22 & $>$ & 1.37 & 2.67 & General adaptation. Stable & 0.75 \\
\hline 4 & 17.28 & $>$ & 1.29 & 0.45 & General adaptation. Stable & 0.59 \\
\hline 5 & 15.06 & $<$ & 0.83 & 2.77 & Poor adaptation. Stable & 0.52 \\
\hline 6 & 16.22 & $<$ & 0.70 & 8.02 & Poor adaptation. Unstable & 0.24 \\
\hline 7 & 14.11 & $<$ & 0.71 & 8.24 & Poor adaptation. Unstable & 0.53 \\
\hline 8 & 16.67 & $>$ & 0.82 & 0.33 & General adaptation. Stable & 0.46 \\
\hline 9 & 21.17 & $>$ & 0.98 & 1.57 & General adaptation. Stable & 0.40 \\
\hline 10 & 13.44 & $<$ & 0.84 & 4.36 & Poor adaptation. Stable & 0.47 \\
\hline 11 & 20.06 & $>$ & 1.42 & 3.47 & General adaptation. Stable & 0.59 \\
\hline 12 & 13.78 & $<$ & 0.96 & 14.09 & Poor adaptation. Unstable & 0.58 \\
\hline 13 & 17.67 & $>$ & 1.27 & 10.25 & General adaptation. Stable & 0.52 \\
\hline
\end{tabular}


a regressor variable, is not independent of the data analyzed. Furthermore, the regression coefficients may be biased because the independent variable is measured without error. In contrast, Skroppa (1984) stated in their review that a regression approach would be statistically valid given a large number of genotypes, environments and replicates, without considering the outliers of each genotype or the environmental effect and assuming homogeneous variance errors for genotypes.

Of the three methodologies used, the Lin and Binns method is the easiest to apply and interpret because it always associates higher productivity with greater stability and presents no restrictions on the use of regression. However, it is necessary to gather more information on the behavior of these indexes prior to their widespread use.

\section{Acknowledgments}

We wish to thank the Departamento de Ciencias Básicas de la Universidad Nacional de Luján, Buenos Aires, Argentina for financial support.

\section{Resumen}

\section{L.Abbott, S. Filippini, H. Delfino y S. Pistorale. 2012. Análisis de estabilidad de la producción} de forraje utilizando tres metodologías en Bromus catharticus (cebadilla criolla). Cien Inv. Agr. 39(2): 331-338. Trece genotipos de B. catharticus (cebadilla criolla) fueron evaluados para producción de forraje durante tres años, utilizando un ensayo completamente aleatorizado, con seis repeticiones. La interacción genotipo $\mathrm{x}$ ambiente fue estadísticamente significativa e indica un comportamiento diferencial de los genotipos evaluados a través de los años. Una vez detectada la interacción, se utilizaron tres metodologías para evaluar la estabilidad de los genotipos: la ecovalencia de Wricke, el Índice de Lin y Binns y el modelo de Eberhart y Russell. Las metodologías de Lin y Binns y de Eberhart y Russell coinciden en indicar a los genotipos 11, 9, 3 y 4 como estables. También son coincidentes para descartar para una posible selección a los genotipos 2, 10, 1 y 12, por su falta de estabilidad o su pobre adaptación. Entre estos índices la correlación fue estadísticamente significativa $(\mathrm{r}=0,61)$. Según la ecovalencia de Wricke sólo hay coincidencia para la selección de los genotipos 9 y 4, que muestran buena estabilidad, pero no hay coincidencia, con los otros dos métodos, en descartar por inestables a ninguno de los genotipos. Considerando las tres metodologías usadas, la de Lin y Binns es fácil de aplicar e interpretar, ya que siempre asocia mayor productividad con mayor estabilidad, y no presenta las restricciones de uso de la regresión. Sin embargo, es necesario acumular muchos resultados antes de proceder a la generalización de su uso.

Palabras clave: Bromus, cebadilla criolla, estabilidad fenotípica, interacción genotipoambiente, producción de forraje.

\section{References}

Allard, R.W. 1960. Principles of plant breeding. John Wiley \& Sons. London. 485 pp.

Becker, H.C. 1981. Correlations among some statistical measures of phenotypic stability. Euphytica 30: $835-840$.
Campbell, B.T., and M.A. Jones. 2005. Assessment of genotype $\mathrm{x}$ environment interactions for yield and fiber quality in cotton performance trials. Euphytica 144: 69-78.

Celis de la Rosa, A.J. 2008. Bioestadística. $2^{\circ}$ edición. Editorial El Manual Moderno S.A. México. 351 pp. 
Chaves, L.J. 2001. Interação de genótipos com ambientes. In: Nass, L.L., Valois, A.C.C., Melo, I.S., Valadares-Inglis, M.C. (eds.). Recursos genéticos e melhoramento Planta: Rondonópolis: Fundação MT. p. 673-713.

Cruz, M.R., and G.M. Salazar. 1992. Métodos alternativos en el análisis de la interacción genotipo-ambiente. Memorias Simposio Interacción Genotipo-Ambiente en genotecnia vegetal. Publicado por SOMEFI (Sociedad Mexicana de Fitotecnia), Guadalajara, México. p. 127-148.

Cruz, C.D., A.D. Regazzi, and P.C.S. Carneiro. 2004. Modelos biométricos aplicados ao melhoramento genético. Universidade Federal de Viçosa. Viçosa, Brasil. 480 pp.

Eberhart, S.A., and W. A. Russell. 1966. Stability parameters for comparing varieties. Crop Sciences 6: $36-40$.

Guillen, R.H. 2002. Variabilidad genética en caracteres de interés agronómico en agropiro alargado (Thinopyrum ponticum (Podp.) Barkworth et Dewey) cultivar "El Vizcachero INTA". Tesis de Magister Scientiae. Maestría en Genética avanzada. Universidad Nacional de Rosario, Santa Fe, Argentina. 168 pp.

Heinrich, G.M., C.A. Francia, and J.D. Eastin. 1983. Stability of grain sorghum yield components across diverse enviroments. Crop Science 23: 209-212.

Jewis, O.R. 1972. Tillering in grass: its significance and control. Grass and Forage Science 27: 65-82.

Johnson, R.A., and D.W. Wichern. 2007. Applied Multivariate Statistical Analysis, $5^{\circ}$ edition New Jersey: Prentice Hall. 816 pp.

Laing, D.R. 1978. Adaptabilidad y estabilidad en el comportamiento de plantas de fríjol común. Centro Internacional de Agricultura Tropical (CIAT). Cali, Colombia. 23 pp.
Lin C.S., M.R. Binns, and L.P. Lefkovitch. 1986. Stability analysis: Where do we stand? Crop Science 26: 894-900.

Lin, C.S., and M.R. Binns. 1988. A superiority measure of cultivar performance for cultivar $\mathrm{x}$ location data. Canadian Journal of Plant Science 68: 193-198.

Magari, R., and M. Kang. 1993. Genotype selection via a new yield stability statistic in maize yield trials. Euphytica 70: 105-111.

Pandey, S., and J.E. Vargas. 1985. La interacción fenotipo-medio ambiente y su importancia en el mejoramiento intrapoblacional en las plantas cultivadas. Trabajo presentado en el VII Congreso Latinoamericano de Genética I Congreso Colombiano de Genética. Bogotá, Colombia. 38 pp.

Peña, D. 2002. Análisis de Datos Multivariantes. Ediciones McGraw-Hill. 529 pp.

Simmonds, N.W. 1979. Principles of crop improvement. Longman. NY. 408 pp.

Skroppa, T. 1984. A critical evaluation of methods available to estimate the genotype $\times$ environment interaction. Studia Forestalia Suecica 166: 3-14.

Wricke, G. 1962. Cinc mehtodo zer ertussog der okojogischen streobrelte in Felder. Versochen Z. Oflanzenzucht 47: 92-96.

Yang, R., and R. Baker. 1991. Genotype-environment interactions in two wheat crosses. Crop Science 31: 83-87.

Wolff, R., L. Abbott, and S. Pistorale. 2006. Estimation of genetic parameters in Bromus catharticus Vahl. Journal of Basic and Applied Genetics 17: 51-59.

Zarrough, K.M. 1983. Relationship between tillering and forage yield of tall fescue. I. Yield. Crop Science 23: 333-337. 